\begin{tabular}{l}
\hline Jurnal Pakarena \\
Volume 3 No 2, Desember 2018 \\
e-ISSN: 2550-102X dan p-ISSN: 1693-3990 \\
\begin{tabular}{|l|l|} 
(c) (1) This work is licensed under a Creative Commons Attribution \\
P.O International License
\end{tabular}
\end{tabular}

\title{
BATIK LONTARA SEBUAH AFIRMASI IDENTITAS DAN LEGITIMASI BUDAYA BUGIS-MAKASSAR
}

\section{Damar Tri Afrianto}

Keywords :

Batik Lontara; Identitas;

Legitimasi Budaya

\section{Corespondensi Author}

Fakultas Seni Rupa dan

Desain, Program Di Luar

Domisili Institut Seni

Indonesia Surakarta Embrio

Institut Seni Dan Budaya

Indonesia di Sulawesi Selatan

damar.tri.a@gmail.com

\begin{abstract}
ABSTRAK
Penyebaran batik meluas dan menyebar terutama di kota-kota besar di Indonesia saat ini terkhusus Kota Makassar Sulawesi Selatan. Makassar, meskipun tidak bersingungan secara langsung dengan sejarah awal kemunculan batik, saat ini komoditas batik di kota daeng tersebut tumbuh pesat. Batik Lontara, adalah batik yang menjadi identitas Makassar saat ini. Batik Lontara merupakan perwujudan batik dengan menggunakan aksara lontara sebagai ide dalam pembentukan motif dan pola. Batik Lontara kini menjadi kebanggaan Kota Makasssar, dengan di munculkannya motif lontara menguatkan identitas budaya terutama suku BugisMakassar. Batik bertransformasi dari kebutuhan sandang menjadi sebuah media mengkomunikasikan suatu identitas. Perubuhan nilai yang melekat pada Batik Lontara di Makassar memunculkan permasalahan terkait afirmasi identitas melalui kesejarahan dan budaya. Rumuskan permasalahan terkait yaitu bagaimana bentuk batik lontara serta fungsinya sebagai afimasi identitas Kota Makassar serta, bagaimana Batik lontara menjadi legitimasi sejarah melalui aksara lontara sebagai ide perwujudan motif batik lontara. Penilitian ini menggunakan domain teori identitas dan metode deskriptif kualitatif, menghasilkan beberapa pemahaman diantaranya; Batik Lontara dapat menunjukkan ekspresi identitas pribadi maupun identitas kolektif. Penggunaan batik lontra pada aspek formal dan kedinasaan tidak hanya membangkitkan esprit de corps di kalangan mereka, tetapi juga menyiratkan berhasilnya ideologi penyeragaman selera berbusana dan pembentukan identitas kolektif dari kelas sosial birokrat yang merasa
\end{abstract}


Damar Tri Afrianto, Batik Lontara Sebuah Afirmasi Identitas dan Legitimasi Budaya BugisMakassar, hlm 22-32.

berada di lapis atas strata sosial. Di sini, gaya busana merupakan suatu indikator status identitas yang jelas.Selain memiliki kekuatan dalam afirmasi identitas, Batik Lontara dalam pembahasaan ini menunjukan bahwa ada upaya melegitimasi kebudayaan dengan menyematkan aksra lontara sebagi motif batik. Di sisi lain, Batik lontara merupakan praktik konservasi yaitu dengan memperkenalkan kembali akasara Lontara dalam bentuk alternatif.

\section{PENDAHULUAN}

Keberadaan kain tradisional Nusantara tidak hanya menyajikan aspek keindahan saja, namun dibalik keindahan kain tersebut tersirat ketekunan dalam menghasilkan karya seni yang didasari dari nilai serta falsafah-falsafah hidup. Melalui kain tradisional Nusantara kita dapat melihat kekayaan warisan budaya yang merupakan representasi dari adat istiadat, kebudayaan, serta kebiasaan budaya (cultural habit). Kreatifitas dan ketajaman berfikir dari seorang penenun dalam mengejawantahkan kebudayaan setempat telah menghasilkan lembaran-lembaran kain yang yang selayaknya kita lestarikan.

Kain tradisional Nusantara mempunyai peranan penting dalam masyarakat karena keberadaannya melekat hampir diseluruh aktifitas kehidupan. Fungsi kain tradisonal dalam aktivitas masyarakat tidak hanya sebatas memenuhi kebutuhan sandang, namun juga untuk upacara lingkaran kehidupan. Upacaraupacara tersebut salah satunya meliputi upacara kelahiran, pemberian nama anak yang baru lahir, inisiasi anak meningkat remaja seperti pong gigi dan khitanan, perkawinan, penobatan kepala suku, serta kematian.

Dari sekian banyak kekayaan kain nusantara kita mengenal batik. Jenis kain yang sangat populer melintas zaman. Pada saat mendengar kata batik, rujukan pertama adalah pada jenis kain yang dibuat secara khusus mengikuti motif-motif tertentu. Tentu itu adalah pengertian secara umum. Secara khusus batik merupakan teknik pemberian warna pada media kain dengan cara menutup bagian yang tidak dikehendaki untuk diwarna menggunakan lilin atau biasa disebut malam. Teknik menorehkan nya dengan alat yang bernama canting, teknik tersebut dikenal dengan batik tulis.

Suyanto (2002: 2-3) menjelaskan bahwa batik menjadi sangat populer dan menjadi nama kain yang dibuat dengan teknik celup rintang dengan media perintang berupa lilin. Istilah tersebut sudah ada sejak jaman kerajaan dan akhirnya menjadi kerajinan rakyat. Tentang sejarah batik banyak ahli yang berpendapat dengan dua ketegori. Pertama, asal mula batik datang ke Indonesia bersamaan dengan masuknya agama Hindu dan Budha dari India. Kedua, batik adalah produk budaya asli Nusantara dengan berdasarkan kenyataan bahawa teknik pembuatan batik terdapat di beberapa daeerah yang tidak mendapat pengaruh agama Hindu dan Budha, yaitu di Toraja, Flores dan Irian Jaya (Kusni Asa, 2006: 17)

Seni batik merupakan keahlian turun-temurun dan merupakan salah satu 
sumber kehidupan yang meberikan lapangan kerja yang cukup luas bagi masyarakat (Susanto, 1980: 1). Oleh karenanya, selain memiliki nilai simbolis melaui beragam motifnya, batik memiliki nilai komoditif yang strattegis. Nilai komoditif batik telah berlangsung lama di Indonesia. Fakta sejarah membuktikan bahwa tahun 1911 berdiri Sarekat Dagang Islam (SDI) yang didirikan oleh $\mathrm{H}$. Samanhudi yang bergerak di bidang perdagangan batik dan kooperasi batik di Jawa.

Batik mengalami perkembangan yang sangat signifikan. Nilai komoditif dari batik seolah mendapat tempat di zaman globalisasi dan teknologi saat ini. Kemudian, batik jenis baru muncul yang dikenal dengan batik cap, sementara batik yang masih dikerjakan dengan tulis tangan juga masih terawat dan terjaga nilainilainya.

Dengan adanya nilai komoditif dan pengaruh globlalisasi ini keberadaan batik berdifusi ke beberapa penjuru daerah. Penyebaran batik meluas dan menyebar terutama di kota-kota besar di Indonesia saat ini terkhusus Kota Makassar Sulawesi Selatan. Makassar, meskipun tidak bersingungan secara langsung dengan sejarah awal kemunculan batik, saat ini komoditas batik di kota daeng tersebut tumbuh pesat. Pada awalnya, batik yang produksi dari Jawa dikirim untuk diperdagangan di Makassar untuk kebutuhan sandang, namun hubungan perdagangan bilateral tersebut justru menumbuhkan ruang-ruang kreatif. Melalui seniman dan desainer, batik Makassar mulai mencanangkan identitasnya.

Motif-motif baru bermunculan guna menandai kebangkitan batik di
Makassar, seniman dan desainer mulai mengolah kearifan lokal sebagai bahan identitas. Mengingat, Makassar adalah kota yang penuh dengan warisan sejarah dan nilai-nilai budaya yang dapat dikembangkan. Batik Lontara, adalah batik yang menjadi identitas Makassar saat ini. Batik Lontara merupakan perwujudan batik dengan menggunakan aksara lontara sebagai ide dalam pembentukan motif dan pola.

Lontara sendiri berasal dari kata lontar yang merupakan salah satu jenis tumbuhan yang ada di Sulawesi Selatan. Istilah lontara juga mengacu pada literatur mengenai sejarah dan geneologi masyarakat Bugis, salah satunya terdapat pada Sureq La Galigo. Bentuk aksara lontara berasal dari "sulapa eppa wala suji". Wala suji berasal dari kata wala yang artinya pemisah/pagar/penjaga dan suji yang berarti putri. Wala Suji adalah sejenis pagar bambu dalam acara ritual yang berbentuk belah ketupat. Sulapa eppa (empat sisi) adalah bentuk mistis kepercayaan Bugis Makassar klasik yang menyimbolkan susunan semesta, api-air angin-tanah. Huruf lontara ini pada umumnya dipakai untuk menulis tata aturan pemerintahan dan kemasyarakatan. dan salah satu naskah yang paling terkenal adalah La Galigo (Wihanry dan Chan, 2015: 3)

Batik Lontara kini menjadi kebanggaan Kota Makasssar, dengan di munculkannya motif lontara menguatkan identitas budaya terutama suku BugisMakassar. Batik bertransformasi dari kebutuhan sandang menjadi sebuah media mengkomunikasikan suatu identitas. Seperti halnya Umberto Eco dalam Vera (2014:13) bahwa manusia dapat berkomunikasi melalui berbagai medium, 
Damar Tri Afrianto, Batik Lontara Sebuah Afirmasi Identitas dan Legitimasi Budaya BugisMakassar, hlm 22-32.

melalui pakaian manusia dapat mengkomunikasikan identitas diri, kelas sosial dan budaya yang dimiliki.

Perubuhan nilai yang melekat pada

Batik Lontara di Makassar memunculkan permasalahan terkait afirmasi identitas melalui kesejarahan dan budaya. Seberapa besar dampak dari perubuhan nilai tersebut dalam konstruksi sosial di masyarakat. Oleh karenanya, berdasarkan pemaparan di atas dapat rumuskan permasalahan terkait bagaimana bentuk batik lontara serta fungsinya sebagai afimasi identitas Kota Makassar serta Bagaimana Batik lontara menjadi legitimasi sejarah melalui aksara lontara sebagai ide perwujudan motif batik lontara. Rumusan permasalahan tersebut merupakan konsekuensi logis ketika batik lontara di Makassar saat ini dimaknai bukan hanya sekedar kebutuhan sandang semata melainkan terdapat kontruksi nilai di baliknya.

\section{Landasan Teori}

Penelitian ini menggunakan perspektif konstruksi identitas, problem tentang identitas diuraikan melalui praktikpraktik pertandaan terutama tanda atau simbol di dalam Batik Lontara yang bukan hanya dimaknai sebuah pakaian namun upaya untuk mengkonstruk sebuah identitas. Teori identitas diarahkan pada identitas budaya. Dalam praktik komunikasi identitas tidak hanya memberikan makna tentang pribadi seseorang, tetapi lebih jauh dari itu menjadi ciri khas sebuah kebudayaan yang melatar belakanginya. Dan dari ciri khas tersebut seseorang dapat menemukan dari mana orang yang dia kenal.

Mary Jane Collier (1994: 36-44) menawarkan sebuah perspektif alternatif yang dapat meraih dua tujuan sekaligus. Tujuan pertama: memahami mengapa kita dan orang lain berperilaku dengan cara tertentu. Tujuan kedua: mempelajari apa yang bisa kita lakukan untuk meningkatkan kelayakan dan efektivitas komunikasi kita. Kedua tujuan ini bisa diraih dengan memandang komunikasi dari perspektif penentuan peran (enactment) identitas budaya. Identitas budaya merupakan karakter khas dari sistem komunikasi kelompok yang muncul dari situasi tertentu (Iskandar, 2004: 123).

Identitas budaya memfokuskan pada tataran kolektif atas dasar arbitrer dan negosiasi. Terkait penelitian ini Teori identitas budaya digunakan dasar untuk melihat upaya mengkontruksi identitas suatu budaya dalam hal ini Makassar melalui batik Lontara. Teori identitas budaya diperjelas oleh Colier ketika membuat struktur karakter pada identitas budaya yang terkait ekspresi simbol. Collier menjelaskan bahwa identitas budaya terbentuk dari cara masyarakat mengekspresi melalui simbol-simbol inti yang berisi definisi, premis, dan proposisi tentang manusia dan alam. Mereka mengekspresikan keyakinan budaya; menunjukan ide dan konsep sentral dan perilaku sehari-hari, misalnya cara berpakaian atau label atau norma yang dibentuk berdasarkan simbol. Ini mengarahkan apa yang diharapkan dan kriteria untuk memutuskan atau menilai (Iskandar, 2014: 217).

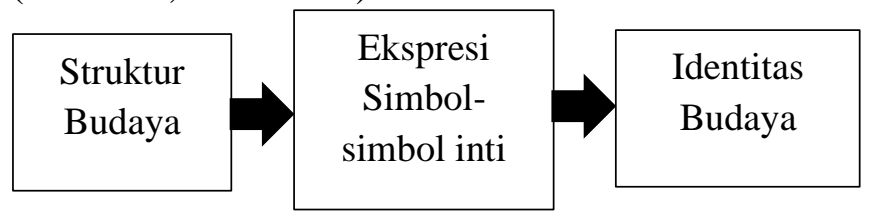

Bagan 1. Pola terbentuknya Identitas Budaya. Adaptasi Penulis, 2020 


\section{Metode Penelitian}

Metode Penelitian berkaitan dengan strategi untuk memahami realita, agar menghasilkan penelitian yang relevan dengan tujuannya, maka rencana penelitian ini diperlukan sebuah metode penelitian berupa cara-cara, strategi-strategi dan langkah-langkah sistematis. Hal ini diharapkan dapat menghasilkan analisis data yang sesuai dengan tujuan penelitian ini.

Bentuk penelitian ini adalah penelitian kualitatif. Data-data dan hasil analisis yang disajiakan berupa deskripsi. Bogdan dan Taylor (dalam Ratna 2010: 94), menjelaskan bahwa kualitatif adalah metode yang pada gilirannya menghasilkan data deskriptif dalam bentuk kata-kata, baik tertulis mapun lisan. Dalam hal ini penelitian kualitatif yang dilakukan tidak semata-mata mendeskripsikan tetapi yang lebih penting adalah menemukan makna yang terkandung di baliknya.

Metode Analisis data kualitatif dimulai pada awal penelitian. Metode analisis dalam penelitian ini menggunkan model interpretasi analisis dengan pendekatan terori identitas budaya dan interaksi analsisi dengan pendekatan holistik. Model interaksi berkaitan dengan proses penyajian. Proses analisis data dengan model interaksi dari awal pengumpulan data, reduksi data, dan penyajian data memiliki sifat jalinmenjalin bergerak dan menjalahi objek selama proses berlangsungnya penelitian. Model ini dipilih karena memungkinkan untuk lebih banyak memberikan satu pencandraan yang mampu menjaring masukan serta paparan dalam rangkuman yang bersifat reduksi data dan penyimpulannya.

\section{Pembahasan}

Kota Makassar yang merupakan pintu gerbang Indonesia Timur berpotensi pada pengembangan pemukiman, perdagangan, jasa, industri, rekreasi, pelabuhan laut, dan tentunya kebudayaannya. Kota yang dijuluki sebagai kota Daeng ini menyimpan beragam sejarah dan budaya yang layak untuk dieksplorasi dan dikembangkan. Beragam budaya tersebut seperti rumah adat, pakaian adat, tari-tarian khas, senjata tradisional, bahasa daerah, serta lagu daerah. Kota Makassar yang merupakan ibu kota Sulawesi Selatan terbagi atas empat suku yakni, suku Makassar, Bugis, Mandar dan Toraja. Tonggak keanekaragaman inilah yang dapat menjadi potensi pembangunan pembangunan secara fisik maupun non fisik.

Warisan budaya yang dimiliki Makassar adalah modal untuk membentuk sebuah identitas, terutama identitas budaya. Kebudayaan tidak cukup hanya sebagai pegangan nilai, namun penting untuk mengkonstruk identitas. Melalui identitas itulah setiap orang atau kelompok diakui dengan kekhasannya. Kehadiran Batik Lontara sebagai ekspresi kolektif patut dilihat sebagai upaya Kota Makassar dalam menciptakan sebuah brand baru, dengan modal budaya tersebut. Tidak diketahui secara pasti awal siapa penggagas batik lontara tersebut, namun di yakini batik tersebut dipengaruhi persebaran batik ke beberapa daerah, dan secara simultan persepsi untuk mengahdirkan motif khas daerah tumbuh pesat.

\section{Bentuk Batik Lontara}

Batik Lontara, adalah batik jenis kontemporer. Batik ini merupakan 
Damar Tri Afrianto, Batik Lontara Sebuah Afirmasi Identitas dan Legitimasi Budaya BugisMakassar, hlm 22-32.

perkembangan dunia mode dan fashion untuk kebutuhan sandang. Batik Lontara tidak seperti batik tradisional yang memiliki pakem terkait aturan siapa boleh dan tidaknya mengenakan sesuai status kebangsawaanannya. Batik lontara adalah batik egaliter yang setiap masayarakat bisa memakainya dari kalangan bebasa nilai. Pada awalnya batik ini merupakan produk komoditif, sebagai konsekuensi penyebaran batik di beberapa tempat, juga karena pihak pemerintah pusat yang melegitimasikan bati sebagai pakain nasional, resmi dan formal.

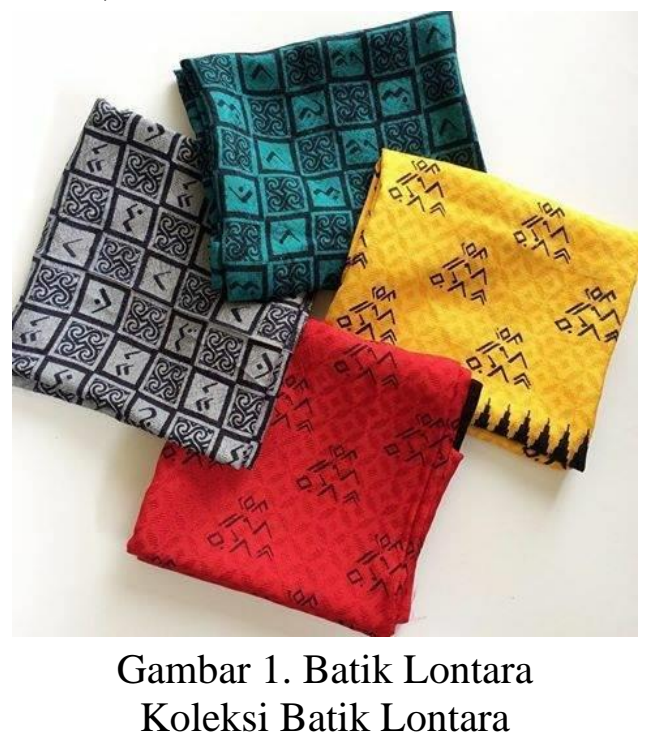

Di Makassar, Batik Lontara mudah ditemui di beberapa tempat dan outlet. Karakteristik batik lontarak, didominasi penyusunan huruf lontara secara abstrak. Ada juga komposisis penyusunan huruf lontara yang ketika dibaca mengandung petuah-petuah leluhur.

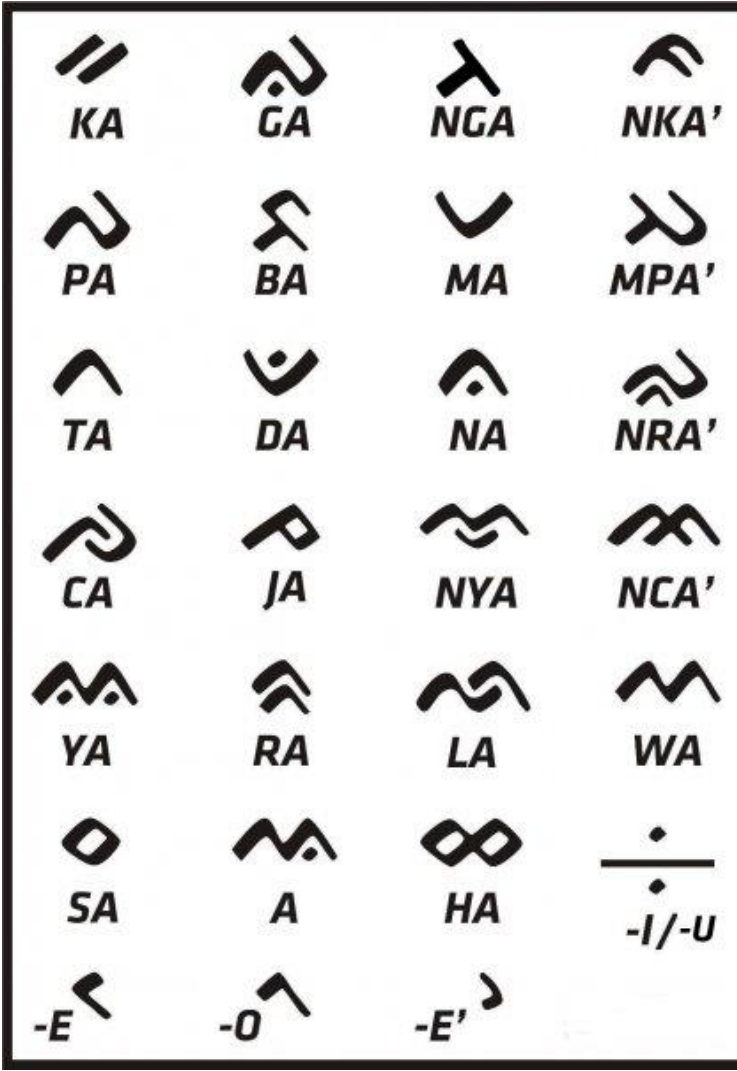

Gambar 2. Aksara Lontara Sumber: Sulengka.Net

Dengan mengunakan huruf aksara lontara sebagai motif batik, desainer batik dapat mengembangkan melaui penyusanan huruf hingga membentuk sebuah kalimat, atau penyusunan abstrak yang hanya mempertimbangan sifat estetis. Karakter huruf Lontara yang beragam dari sifat geometris dan biomorfis memiliki sifat flekasibel jika dikomposisikan sebagai motif dan pola batik. 


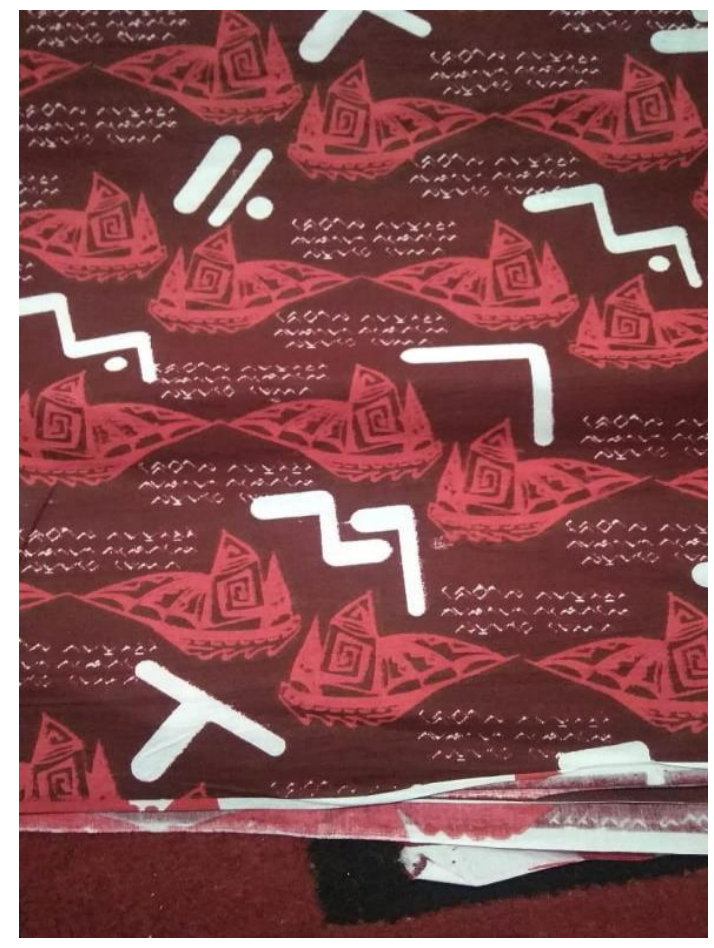

Gambar 3. Inovasi Batik Lontara Foto: Koleksi Lini Studio Makassar

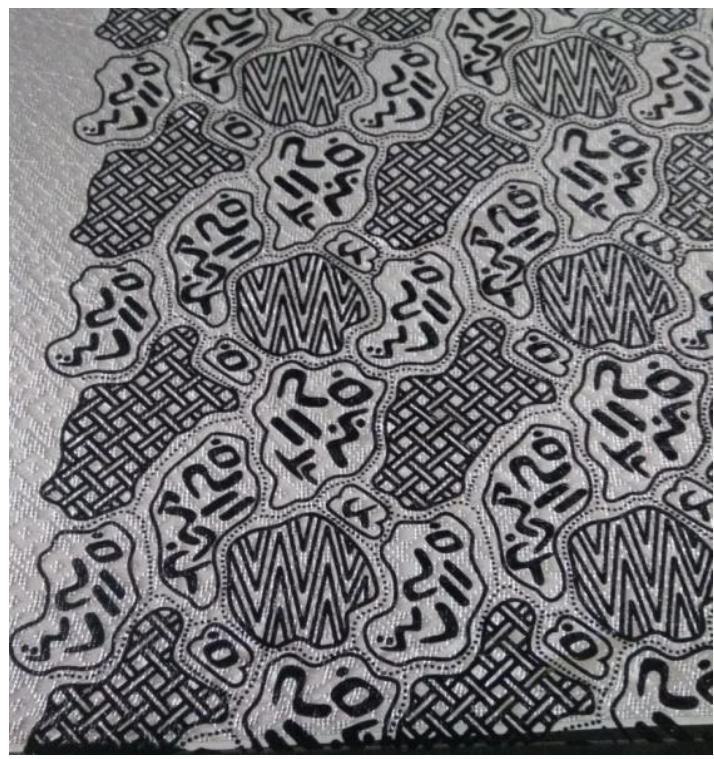

Gambar 4. Inovasi Batik Lontara

Foto: Koleksi Lini Studio Makassar

Pilihan beragam warna juga sangat fleksibel ketika disematkan dengan aksara lontara tersebut, tentu permintaan dari konsumen menjadi dasar pertimbangan selain juga kebutuhan estetis pula. Secara garis besar, batik lontara menggunakan bahan aksara sebagai motif dan pola batik.
Penyematan aksara ke dalam motif selain kebutuhan estetis, juga menjadi menjadi infografis yang dapat dibaca karena berlandasakan aksara.

\section{Batik Lontara sebagai medium Afimasi Identitas}

Kehadiran Batik Lontara menandai sebuah identitas budaya baru yang disematkan dalam pakaian atau sandang di zaman modern. Jauh sebelum itu, simbol identitas budaya ditandai dengan adanya pakaian tradisonal atau pakaian adat. Setiap masyarakat memilki hasrat terusmenerus untuk menadai dirinya (identitas) sebagai bentuk komunikasi dan pembeda dengan yang lain. Weeks turut menyatakan dalam Barker (2013: 174), identitas adalah kesamaan Anda dengan sejumlah orang dan apa yang membedakan Anda dari orang lain.

Batik Lontara adalah budaya pop yang mengeskplorasi lokalitas dalam mengkonstruksi identitas terutama Kota Makassar. Hal ini dibuktikan dengan fungsi batik lontara tidak hanya berhenti pada sebuah mode dan fashion tapi sebagai komunikasi identitas budaya. Identitas budaya tersebut disebar luaskan dengan hadirnya seragam-seragam batik pada instansi pemerintahan. Seperti, diketahui pemerintah adalah agen sentral untuk memperluar jargan identitas budaya.

Hadirnya Batik Lontara sebagai seragam kedinasaan pada instansi pemerintahan merupakan penanda awal fungsi afirmasi identitas di Makassar. Fungsi seragam tentu bukan hanya pakaian tapi menunjukan kekuatan kolektifitas sebagai identitas. Batik Lontara berhasil menjadi medium afirmasi identitas ketika diperkuat kebijakan terkait fungsi batik 
Damar Tri Afrianto, Batik Lontara Sebuah Afirmasi Identitas dan Legitimasi Budaya BugisMakassar, hlm 22-32.

lontara sebagai pakaian formal dan pakaian kedinasan. Di sini ketika melihat adanya konstruksi sosial yang tengah dibangun oleh Kota Makassar melalui Batik lontara.

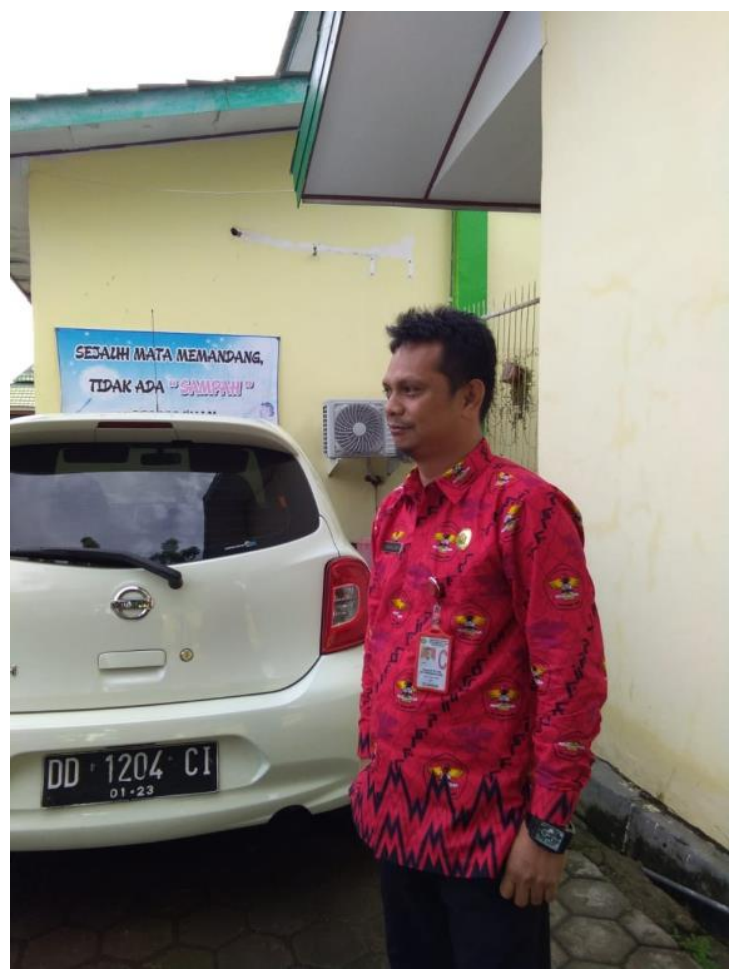

Gambar 5. Batik Lontara Sebagai pakaian kedinasan

Foto: Koleksi Lini Studio Makassar

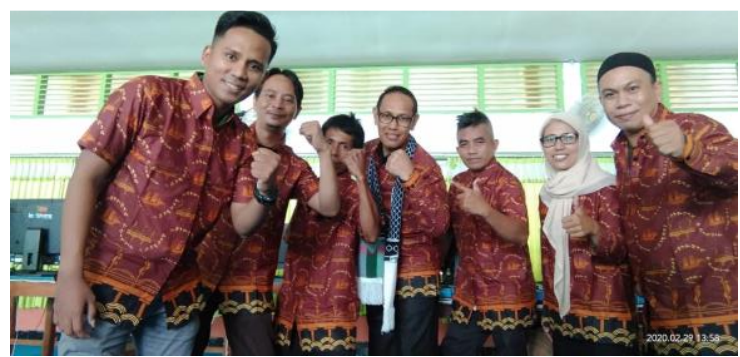

Gambar 6. Batik Lontara Sebagai pakaian kedinasan

Foto: Koleksi Lini Studio Makassar

Penyeragaman instansi pemerintah dengan Batik Lontara menjadi identitas sekaligus upaya ikonik kota Makassar. Praktik-praktik penggunaan batik lontara sebagai afirmasi identitas tidak hanya berhenti pada seragam kedinasan, ada upaya yang lebih memiliki pengaruh siginifikan yaitu dengan peran publik figur. Peran publik figur sangatlah strategis dalam mengafirmasi identitas budaya. Publik figur merupakan agen penyebaran sebuah ideologi dari kalangan atas hingga ke lapisan masyarakat. Hal ini dilakukan oleh mantan Walikota Makasasar Danny Pomanto dan Mantan Gubenur Sulawesi Selatan yang pada periode ini menjadi Menteri Pertanian, Syarul Yasin Limpo. Kedua tokoh tersebut memiliki peran menyebarkan kebanggaan identitas kebudayaan dengan menggunaan batik lontara.

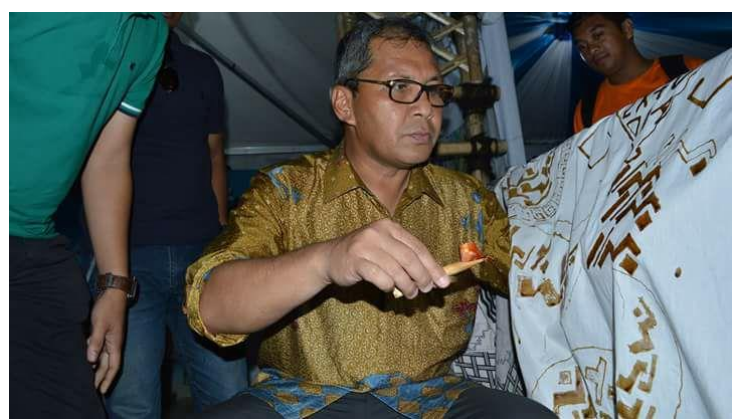

Gambar 7. Danny Pomanto (Mantan

Walikota Makassar) mempraktekan batik Lontara

Foto: Koleksi Batik Lontara Makassar 


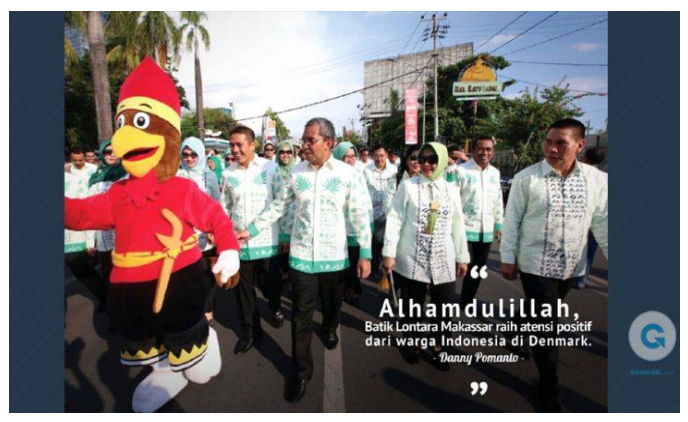

Gambar 8. Danny Pomanto (Mantan Walikota Makassar) mengenakan Batik Lontara beserta jajarannya Sumber: https://gosulsel.com/2016/06/08/batiklontara-raih-atensi-positif-dari-wargaindonesia-di-denmark/

Tidak hanya Danny Pomanto yang membranding Batik lontara sebagai identitas, Menteri Pertanian Syahrul Yassin Limpo yang juga mantan Gubenur Sulawesi Selatan memanfatkaan momen penting saat perkenalan menteri-menteri Kabinet Jokowi dengan mengenakan Batik Lontara. Hal tersebut adalah bentuk upaya publik figur membawa identitas budaya lokal dalam konteks nasional.

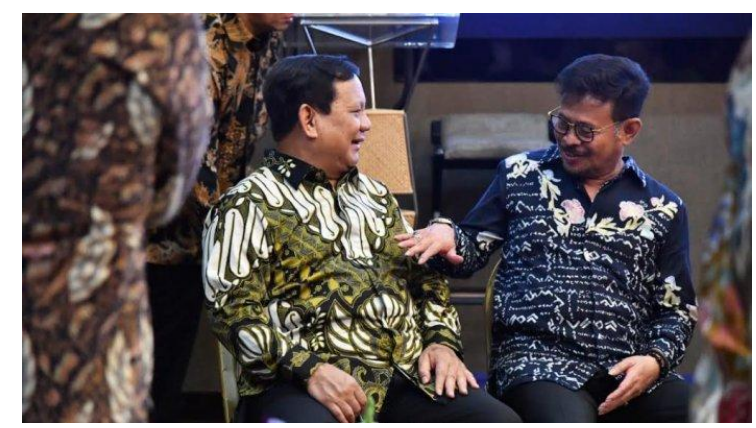

Gambar 9. Menteri Pertanian Syarul Yassin Limpo mengenakan Batik Lontara dalam acara perkenalan Menteri Kabinet Jokowi

Sumber:

https://makassar.tribunnews.com/2019/10/ $\underline{241}$

Publik figur memiliki peran strategis dalam menyebarkan sebuah identitas milik suatu budaya tertentu. Dua tokoh publik figur di atas, tidak hanya sedang memperkenalkan Batik Lontara kepada khayalak luas, namun juga meneguhkan sebuah identitias, atau afirmasi identitas serta secara tidak langsung melegitimasi budayanya dalam hal ini budaya Sulawesi Selatan khususnya Makasssar.

\section{Batik Lontara Sebagai Upaya Legitimasi Budaya}

Kebudayaan suatu daerah mewujud kedalam beberapa hal, Koentajraningrat membaginya menjadi tiga, Ideafact, Sosifact, dan artefact. Dalam kasus ini, batik lontara merupakan sebuah ekspresi di dalam konteks modernitas dalam bentuk artefact atau kebendaaan. Meski lahir dan berkembang di periode modern, Batik Lontara secara tidak langsung mengenalkan sebuah warisan budaya yaitu aksara lontara milik suku Bugis-Makassar. Lontara adalah manuskrip yang aslinya ditulis dengan alat yang tajam di atas daun lontar (rontal), kemudian dibubuhi dengan cairan warna hitam pada bekas goresan itu. Setelah ditemukannya kertas sebagai alat tempat menulis, maka daun lontar diganti, tetapi nama Lontara masih tetap terpakai.

Pada awalnya, kesusastraan suci orang Bugis diwarisi secara lisan, kemudian diabadikan dalam karya tulis berupa mantera-mantera dan kepercayaankepercayaan mitologi. Perkembangan selanjutnya, hasil-hasil kesusastraan yang bersifat keduniaan juga berkembang sesuai dengan perkembangan Lontara dan sikap hidup masyarakat serta kebudayaannya. Belum diketahui secara pasti periode kesusastraan suci Bugis yang dikenal dengan Galigo itu. Menurut Mattulada, dilihat dari tema-tema di dalam Galigo 
Damar Tri Afrianto, Batik Lontara Sebuah Afirmasi Identitas dan Legitimasi Budaya BugisMakassar, hlm 22-32.

besar kemungkinan bahwa priode Galigo antara abad ke-7 sampai abad ke-12 yaitu pada masa perkembangan kerajaan Hindu di Nusantara, seperti Sriwijaya, Syailendra dan lain- lain (Mattulada, 1985: 402).

Dengan disematkannya aksara lontara pada motif batik selain afirmasi identitas juga merupakan upaya legitimasi budaya. Legitimasi merupakan keadaan psikologis keberpihakan orang dan kelompok orang yang sangat peka terhadap gejala lingkunagan sekitarnya baik fisik maupun non fisik. Legitimasi dapat dianggap sebagai menyamakan persepsi atau asumsi bahwa tindakan yang dilakukan oleh suatu entitas adalah merupakan tindakan yang diinginkan, pantas ataupun sesuai dengan sistem norma, nilai, kepercayaan dan definisi yang dikembangkan secara sosial (Suchman, 1995 dalam Kirana, 2009). Oleh karena itu, apa yang sedang dilakukan oleh masayarakat terkait batik lontara adalah tindakan yang diupayakan untuk melegitimasi aksara lontara dalam hal pengembangan sosial dan secara tidak langsung meneguhkan bahwa aksara lontara merupakan kebudayaan dari BugisMakassar.

Legitimasi budaya dalam batik lontara juga dapat dilihat sebagai praktik konservasi yaitu memperkenalkan kembali akasara lontara dalam bentuk lain. Batik dianggap mampu meneyediakan medium bagi upaya infografis, bahwa aksara lontara masih tetap bertahan hidup di dalam zaman globalisasi modern sebagai warisan budaya Bugis-Makassar yang sarat dengan nilai-nilai dan pandangan hidup.

\section{Penutup}

Batik Lontara sebagai identitas Kota Makassar tidak hanya memberi kesan suatu yang indah dipandang mata saja, melainkan memberikan makna yang erat hubungannya dengan budaya dan falsafah hidup melalui aksara lontara yang memebtuk kalimat petuah. Hasil pembahasan di atas menunjukan Batik Lontara dapat menunjukkan ekspresi identitas pribadi maupun identitas kolektif. Penggunaan batik lontra pada aspek formal dan kedinasaan tidak hanya membangkitkan esprit de corps di kalangan mereka, tetapi juga menyiratkan berhasilnya ideologi penyeragaman selera berbusana dan pembentukan identitas kolektif dari kelas sosial birokrat yang merasa berada di lapis atas strata sosial. Di sini, gaya busana merupakan suatu indikator status identitas yang jelas. Begitupun dengan peran paublik figur sangat strategis dalam memeperkuat identitas, dengan mengenakan Batik Lontara di acara-acara nasional, seorang public figur tersebut sedang membawa identitas lokalnya pada kancah yang lebih luas.

Selain memiliki kekuatan dalam afirmasi identitas, Batik Lontara dalam pembahasaan ini menunjukan bahwa ada upaya melegitimasi kebudayaan dengan menyematkan aksra lontara sebagi motif batik. Di sisi lain, Batik lontara merupakan praktik konservasi yaitu dengan memperkenalkan kembali akasara Lontara dalam bentuk alternatif. 


\section{Daftar Pustaka}

A.N Suyanto. 2002. Sejarah Batik Yogyakarta. Yogyakarta: Rumah Merapai

Collier, Mary Jane, 1994, "Cultural Identity and Intercultural Communication", dalam Samovar, Larry A. dan Porter, Ricard E. (eds), Intercultural Communication: A Reader, Berlmont: Wadsworth, h. 36-44.

Darmaputri, Gabriela Lordy. Representasi Identitas Kultural Dalam SimbolSimbol Pada Batik Tradisional Dan Kontemporer. Jurnal Commonline Departemen Komunikasi. Vol. 4/ No. 2

Iskandar, Dadan. Identitas Budaya Dalam Komunikasi Antar-Budaya: Kasus Etnik Madura dan Etnik Dayak Jurnal Masyarakat dan Budaya, Volume 6 No. 2 Tahun 2004

Kirana, R. S. 2009. Studi Perbandingan Pengaturan Tentang Corporate Social Responsibility Di Beberapa Negara Dalam Upaya Perwujudan Prinsip Good Corporate Governance. Tesis Program Studi Magister Ilmu Hukum Program Pascasarjana Universitas Sebelas Maret (tidak dipublikasikan).

Kusni Asa. 2006. Batik Pekalongan Dalam Lintasan Sejarah, Paguyuban Pencinta Batik Pekalongan.

Mattulada. 1985. Latoa: Suatu Lukisan Analitis terhadap Antropologi Politik Orang Bugis, Yogyakarta: Universitas Gaja Mada.

Miles, Matthew B. \& A. Michael Huberman Analisis Data Kualitatif. Terj. Tjetjep Rohendi

Ratna, Nyoman Kutha. Metode Penelitian: Kajian Budaya dan Ilmu Sosial Humaniora Pada Umumya. Yogyakarta. Pustaka Pelajar, 2010.

Susanto, Sewan. 1980. Seni Kerajinan Batik Indonesia. Balai Penelitian Batik Dan Kerjinan
Vera, Nawiroh. Semiotika dalam Riset Komunikasi. Bogor: Ghalia Indonesia, 2014

Wihanry, Indra. Phie Chyan. 2015. Perancangan Aplikasi Pembelajaran Aksara Lontara dengan Metode Game Based Learning. Jurnal Tematika Vol. 1 No.1,

Sumber Internet:

https://gosulsel.com/2016/06/08/batiklontara-raih-atensi-positif-dari-wargaindonesia-di-denmark/

https://makassar.tribunnews.com/2019/10/2 $\underline{41}$ 